\title{
Efektifitas Pendidikan Kesehatan Menggunakan Media Audio Visual dan Poster terhadap Perilaku Ibu Primipara dalam Manajemen Laktasi
}

\author{
${ }^{1}$ M.Sholehah*, ${ }^{2}$ Kholisotin, ${ }^{3}$ Z. Munir \\ 1,2,3 Program Studi Keperawatan, Fakultas Kesehatan, Universitas Nurul Jadid \\ *Email Korespondensi: maghfirotussholehah@gmail.com
}

Kata kunci :

Pendidikan kesehatan; Manajemen Laktasi;

ASIEkslusif;

Keywords :

Health Education;

Lactation Management;

Exclusive Breast Milk;

Info Artikel:

Tanggal dikirim:

6 Agustus 2019

Tanggal direvisi:

4 September 2019

Tanggal diterima :

10 Oktober 2019

DOI Artikel:

10.33862/citradelima.

v3i2.67

Halaman: 110 - 117

\begin{abstract}
Abstrak
ASI merupakan cairan emulsi lemak yang dihasilkan dari kelenjar mamae pada ibu menyusui. Ibu primipara yang memberikan ASI tidak tahu tentang cara menyusui dengan benar dan tidak mengetahui cara memerah ASI. Pendidikan kesehatan manajemen laktasi pada ibu primipara penting untuk merubah perilaku ibu primipara yang menyusui. Media yang digunakan audio visual dan Poster. Penelitian ini bertujuan untuk mengetahui pengaruh pendidikan kesehatan menggunakan media audio visual dan poster terhadap perilaku ibu primipara dalam manajemen laktasi. Desain penelitian ini mengggunakan quasi eksperiment dan menggunakan rancangan penelitian two group pre-posttest design dengan jumlah sampel 40 responden ibu primipara, 20 kelompok audio visual, 20 kelompok poster. Analisa data yang digunakan Uji Wilcoxon dan Independent $\mathrm{T}$ test. Hasil yang diperoleh ada perbedaan perilaku sebelum dan sesudah dilakukan penddidikan kesehatan $(\mathrm{p}=0,00)$. Tidak ada perbedaan yang signifikan antara kelompok audio visual dan poster dengan nilai $(\mathrm{p}=0,77)$, dengan Kesimpulan dari hasil penelitian adalah Ada pengaruh perilaku ibu primipara dalam manajemen laktasi sebelum dan sesudah dilakukan pendidikan kesehatan pada kelompok audio visual dan poster. Tidak ada perbedaan efektifitas pendidikan kesehatan terhadap perilaku ibu primipara dalam manajemen laktasi pada kelompok audio visual dan kelompok poster.
\end{abstract}

\section{The Effectiveness of Health Education Using Audio-Visual Media and Posters Against Primipara Mother's Behavior in Lactation Management}

\begin{abstract}
ASI (breast milk) is a fat emulsion liquid produced from the mammary gland in the nursing mother. Primipara's mother does not know how to breastfeed well and how to milk it. Lactation management health education for Primipara mother is essential to change Primipara's mother's behavior who breastfeeds. They use audiovisual and posters as media. This research has a goal to know about the effects of health education using audiovisual and sign as media on Primipara Mother's behavior in Lactation Management. The design of this research uses Quasi-experiment and uses two groups of pre-posttest design. It takes or about 40 Primipara mothers as respondents. It is divided into two groups. They are 20 audiovisual groups and 20 posters groups. The data analysis is Wilcoxon and independent test. The result of this research is that there is a difference between before conducting health education and after that $(p=0,00)$. There is not a significant difference between audiovisual and posters $(p=0,77)$. Therefore, from the result of this research is there is an effect of Primipara Mother's Behavior in lactation management nether before conducting health education for audiovisual and posters groups nor after conducting it, and there is no a difference effect health education on Primipara Mother's behavior in lactation management for audiovisual and posters groups
\end{abstract}




\section{PENDAHULUAN}

Melahirkan merupakan karunia terbesar bagi sebuah keluarga terutama bagi wanita, setelah melahirkan setiap wanita akan mengalami masa nifas atau disebut juga masa perineum. Selama masa nifas, organ reproduksi secara perlahan akan mengalami perubahan dari masa sebelumnya baik perubahan fisiologis atau psikologis (Maritalia, 2017).

Ibu yang pertama kali lahir (primipara) tentu berbeda persiapan dan mekanisme kopingnya saat menghadapi masa persalinan, masa nifas, dan menyusui dengan ibu yang sudah pernah melahirkan (multipara). Bila ibu sudah mengenal perawatan diri atau teknik yang akan dilakukan, maka ibu akan lebih mudah dalam melakukam perawatan diri pascasalin (Maritalia, 2017). Merawat bayi baru lahir, seorang ibu butuh pengetahuan dan keterampilan yang cukup tentang bayi baru lahir (BBL), seperti cara menyusui yang baik untuk memberikan Asi ekslusif. Pemberian Asi ekslusif berhungan dengan pengetahuan orang tua, keterampilan orang tua, dan pendidikan orang tua. Faktor berhubungan dengan menyusui diantaranya adalah kurangnya pengetahuan dan kesadaran ibu akan pentingnya pemberian ASI.(Sartono, 2012). Ibu menyusui tidak jarang menghadapi berbagai masalah pemberian ASI, terutama yang berhubungan dengan manajemen laktasi (Roesli, 2008).

Berdasarkan data dari kesehatan Indonesia 2017 Persentasi pemberian ASI ekslusif umur 0-5 bln 46,76 $\%$ umur 0-6 bulan 35,73\%. Inisiasi Menyusui Dini (IMD) kurang dari 1 jam 51;32\%, lebih dari 1 bulan 6,65\% (Kesehatan Indonesia 2017). Berdasarkan data dari kabupaten / kota diketahui bahwa cakupan bayi yang mendapatkan ASI ekslusif di Jawa timur tahun 2016 sebesar 74\% cakupan tersebut mengalami peningkatan dari tahun ketahun sejak 2011 (61,5\%). Di Kabupaten Bondowoso 70\%, secara keseluruhan pencapaian di Jawa Timur (74\%) belum memenuhi target yang telah di tetapkan (77\%) (Kesehatan Jawa Timur, 2017). Berdasarkan studi pendahuluan pada tanggal 06 Desember 2018 di dapatkan beberapa kecamatan masih rendah angka pemberian ASI ekslusif selama 1 tahun terakhir. Seperti, Kecamatan Sempol 47 orang dengan angka kelahiran 140 orang, Kecamatan Sukosari 77 orang dengan angka kelahiran 187 orang, Kecamatan Taman Krocok 87 orang dengan angka kelahiran 193 orang, Kecamatan Klabang 104 orang dengan angka kelahiran 211, Kecamatan Tegalampel
106 orang dengan angka kelahiran 313 orang. (Dinas Kesehatan Bondowoso, 2017).

Berdasarkan data di atas Taman Krocok merupakan no 3 yang masih rendah angka ASI ekslusif, salah satu penyebabnya yaitu kurangnya pengetahuan, Sikap dan keterampilan tentang manajemen laktasi (Notoatmodjo, 2010).

Berdasarkan hasil penelitian Angrenani Oka Artaria (2015) salah satu upaya pemenuhan target dalam pemberian ASI ekslusif dengan memberikan pendidikan kesehatan manajemen laktasi pada ibu primipara. Karena, semakin banyak informasi dapat menambah pengetahuan dan keterampilan seseorang, menimbulkan kesadaran yang akhirnya akan mengubah perilaku seseorang sesuai pengetahuannya (Notoatmodjo, 2010). Oleh karena itu pendidikan kesehatan tentang manajemen laktasi sangat penting untuk ibu primipara, supaya ibu primipara mengetahui pentingnya manajemen laktasi. Manajemen laktasi merupakan segala upaya yang dilakukan untuk membantu ibu mencapai keberhasilan dalam menyusui bayinya. Usaha ini dilakukan dalam tiga tahap, yaitu pada masa kehamilan (antenatal), sewaktu ibu dalam persalinan sampai keluar rumah sakit (perinatal), dan masa menyusui selanjutnya sampai anak berumur 2 tahun (postnatal). (Prasetyono, 2009). Ruang lingkup manajemen laktasi meliputi ASI eksklusif, teknik menyusi, memeras ASI, memberikan ASI peras, menyimpan ASI peras, memberikan ASI peras dan pemenuhan gizi selama ibu periode menyusui. Pada ibu primipara proses ini kadang terlupakan sehingga mengakibatkan produksi ASI tidak maksimal dan berakibat pada penurunan cakupan ASI eksklusif. (Zuhrotul, 2016).

Berdasarkan fenomena tersebut, peneliti tertarik untuk meneliti perilaku ibu primipara dalam manajemen laktasi, dengan harapan untuk meningkatkan pengetahuan ibu dalam manajemen laktasi dengan judul "Efektifitas Pendidikan Kesehatan Menggunakan Media Audio Visual dan Poster Terhadap Perilaku Ibu Primipara dalam Manajemen Laktasi Wilayah Kerja Puskesmas Taman Krocok Bondowoso".

\section{METODE}

Penelitian ini menggunakan pendekatan kuantitatif. Desain yang digunakan dalam penelitian ini adalah rancangan penelitian Quasi Eksperiment

http://jurnalilmiah.stikescitradelima.ac.id/index.php/JI Vol.3,No.2, Januari 2020 
dengan menggunakan rancangan pret-post untuk membandingkan tindakan yang dilakukan sebelum dan sesudah diberilakn perlakuan dan menggunakan jenis rancangan two group design.

Penelitian dilakukan di Puskemas Taman Krocok Bondowoso. Populasi pada penelitian ini sebanyak 40 ibu primipara, teknik sampel yang digunakan adalah total sampling yaitu 20 pada kelompok audio visual, 20 pada kelompok poster. Insrumen penelitian menggunakan kuesioner sebanyak 15 pernyataan pada pengetahuan dan sikap responden dalam melakukan manajemen laktasi dan lembar observasi sebanyak 19 pernyataan pada keterampilan responden dalam manajemen lakatsi.

\section{HASIL DAN PEMBAHASAN}

\section{Karakteristik Responden Berdasarkan Usia}

\begin{tabular}{lllcll}
\hline & & & \multicolumn{3}{c}{ Min } \\
$\mathrm{N}$ & $\begin{array}{c}\text { Respo } \\
\text { nden }\end{array}$ & $\begin{array}{c}\text { Mean } \\
\pm \mathrm{SD}\end{array}$ & $\begin{array}{c}\text { Medi } \\
\text { an }\end{array}$ & $\begin{array}{l}\text { Max } \\
\text { Max }\end{array}$ \\
& & & & & $95 \% \mathrm{CI}$ \\
\hline 1 & $\begin{array}{l}\text { Kelompok } \\
\text { audio }\end{array}$ & $22 \pm 2,16$ & 22 & 19 & $20,0-$ \\
& & & & 23,99 \\
\hline 2 & visual & & & & $20,0-$ \\
& Kelom & $22 \pm 2,16$ & 22 & $19-25$ & 23,99
\end{tabular}

Tabel 1 menunjukkan bahwa usia pada kelompok audio visual didapatkan nilai rata-rata 22 tahun (95\% CI: 20,0+23,99), dengan standar deviasi 2,16 tahun. Umur termuda 19 tahun dan umur tertua 25 tahun. Dari hasil estimasi interval dapat disimpulakn bahwa $95 \%$ diyakini bahwa rata-rata umur responden pada kelompok audio visual adalah diantara 20,0 sampai dengan 23,99 tahun. Sedangkan usia pada kelompok poster didapatkan nilai rata-rata 22 tahun (95\% CI: 20,0- 23,99), dengan standar deviasi 2,16 tahun. Umur termuda 19 tahun dan umur tertua 25 tahun. Dari hasil estimasi interval dapat disimpulakn bahwa 95\% diyakini bahwa rata-rata umur responden pada kelompok intervensi adalah diantara 20,0 sampai dengan 23,99 tahun.
Karakteristik Responden berdasarkan Pendiikan

\begin{tabular}{|c|c|c|c|c|c|}
\hline \multirow{2}{*}{$\begin{array}{l}\mathbf{N} \\
\mathbf{0}\end{array}$} & \multirow{2}{*}{$\begin{array}{c}\text { Variabel } \\
\text { Pendidikan }\end{array}$} & \multicolumn{2}{|c|}{$\begin{array}{l}\text { Audio } \\
\text { visual }\end{array}$} & \multicolumn{2}{|c|}{ Poster } \\
\hline & & $\mathrm{F}$ & $\%$ & $\mathrm{~F}$ & $\%$ \\
\hline 1 & Tamat SD & 6 & 30 & 7 & 35 \\
\hline 2 & $\begin{array}{l}\text { Tamat } \\
\text { SMP/Mts }\end{array}$ & 6 & 30 & 8 & 40 \\
\hline 3 & $\begin{array}{l}\text { Tamat } \\
\text { SMA/MA }\end{array}$ & 7 & 35 & 3 & 15 \\
\hline 4 & $\begin{array}{l}\text { Tamat } \\
\text { Sarjana }\end{array}$ & 1 & 5 & 2 & 10 \\
\hline & Jumlah & $\begin{array}{l}2 \\
0\end{array}$ & $\begin{array}{c}10 \\
0\end{array}$ & 20 & $\begin{array}{c}10 \\
0\end{array}$ \\
\hline
\end{tabular}

Tabel 2 menunjukkan sampel pendidikan terbanyak pada kelompok audio visual yaitu tingkat SMA/ MA sebanyak 7 responden (35\%), sampel terendah pada tingkat sarjana sebanyak 1 responden (5\%). Sampel pendidikan terbanyak pada kelompok poster yaitu tingkat SMP/Mts sebanyak 8 responden (40\%), sampel pendidikan terendah yaitu tingkat sarjana sebanyak 2 responden $(10 \%)$.

Hasil Uji Statistik Wilcoxon Perilaku Ibu Primipara Sebelum dan Sesudah Dilakukan Pendidikan Kesehatan Pada Kelompok Audio Visual dan Poster

\begin{tabular}{lllll}
\hline $\begin{array}{l}\text { Variab } \\
\text { le }\end{array}$ & Mean & SD & $\begin{array}{c}\text { Selisih } \\
\text { Mean }\end{array}$ & $\begin{array}{c}\text { P- } \\
\text { Value }\end{array}$ \\
\cline { 1 - 3 } $\begin{array}{l}\text { Pre } \\
\text { Audiov } \\
\text { isuial }\end{array}$ & 45,65 & 9,43 & 43,62 & 0,000 \\
\cline { 1 - 2 } $\begin{array}{l}\text { Post } \\
\text { Audio }\end{array}$ & 2,03 & 5,66 & & \\
Visual & & & & \\
\cline { 1 - 2 } $\begin{array}{l}\text { Pre } \\
\text { Poster }\end{array}$ & 47,55 & 9,46 & 45,51 & 0,000 \\
\cline { 1 - 2 } $\begin{array}{l}\text { Post } \\
\text { Poster }\end{array}$ & 2,04 & 7,60 & & \\
\hline
\end{tabular}

Tabel 3 menunjukkan rata-rata perilaku sebelum dilakukan pendidikan kesehatan menggunakan audio visual adalah 45,65 sedangkan rata-rata sesudah dilakukan pendidikan kesehatan adalah 2,03 dengan standar deviasi 5,66. Terlihat nilai mean perbedaan antara sebelum dan sesudah adalah 43,62. Hasil uji statistik didapatkan nilai $\mathrm{p}=0.00$ dan $\alpha=0,05(\mathrm{p}<\alpha)$. Sedangkan rata-rata perilaku sebelum dilakukan pendidikan kesehatan menggunakan poster adalah 47,55 sedangkan rata-rata sesudah dilakukan pendidikan kesehatan adalah 2,04 dengan standar

http://jurnalilmiah.stikescitradelima.ac.id/index.php/JI Vol.3,No.2, Januari 2020 
deviasi 7,60. Terlihat nilai mean perbedaan antara sebelum dan sesudah adalah 45,51. Hasil uji statistik didapatkan nilai $\mathrm{p}=0.00$ dan $\alpha=0,05(\mathrm{p}<\alpha)$ maka dapat disimpulkan ada pengaruh yang signifikan pada perilaku responden sebelum dan sesudah dilakukan pendidikan kesehatan menggunakan audio visual dan poster.

Hasil Uji Statistik Independent T-Test Perilaku Sesudah Dilakukan Pendidikan Kesehatan Pada Kelompok Audio Visual dan Poster.

\begin{tabular}{|c|c|c|c|c|c|}
\hline Variable & Mean & SD & $\begin{array}{l}\text { Selisih } \\
\text { Mean }\end{array}$ & $\begin{array}{l}\mathbf{S} \\
\mathbf{E}\end{array}$ & $\begin{array}{c}\text { P- } \\
\text { Valu } \\
\text { e }\end{array}$ \\
\hline $\begin{array}{l}\text { Post } \\
\text { perilaku } \\
\text { audiovis } \\
\text { ual }\end{array}$ & 2,03 & 5,66 & $\mathbf{0 , 0 1}$ & $\begin{array}{l}1,2 \\
6\end{array}$ & $\mathbf{0 , 7 7}$ \\
\hline $\begin{array}{l}\text { Post } \\
\text { perilaku } \\
\text { poster }\end{array}$ & 2,04 & 7,60 & & $\begin{array}{l}1,7 \\
0\end{array}$ & \\
\hline
\end{tabular}

Tabel 4 didapatkan hasil uji statistik menggunakan Independent T-Test sesudah dilakukan pendidikan kesehatan pada perilaku kelompok audio visual didapatkan nilai rata-rata 2,03 dengan standar deviasi 5,66. Sedangkan perilaku pada kelompok poster didapatkan nilai rata-rata 2,04 dengan selisih mean 0,01 dan dengan standar deviasi 1,70. Hasil uji statistic didapatkan $\mathrm{p}=0,77$ dan $\alpha=0,05(\mathrm{P}>\alpha)$ yang artinya tidak ada perbedaan yang signifikan perilaku sesudah dilakukan pendidikan kesehatan pada kelompok audio visual dan kelompok poster.

\section{Karakteristik Responden Berdasarkan Usia}

Usia ibu primipara pada penelitian ini menunjukkan bahwa pada kelompok audio visual dan poster rata-rata berusia 22 tahun. Umur termuda 19 tahun dan umur tertua 25 tahun. Dari hasil estimasi interval dapat disimpulakn bahwa 95\% diyakini bahwa rata-rata umur responden pada kelompok audio visual adalah diantara 20 sampai dengan 23 tahun.

Manajemen laktasi merupakan suatu proses yang berkelanjutan mulai dari kehamilan sampai dengan masa menyusui. Salah satu faktor yang dapat mempengaruhi perubahan perilaku adalah faktor usia. Menurut Sarwono, Melalui perjalanan umurnya semakin dewasa umur individu maka lebih mudah untuk beradaptasi sikap dan perilaku hidupnya dengan lingkungan. Hasil penelitian sebelumnya yang dilakukan oleh zuhrotul (2016) diperoleh kriteria paling banyak dengan kriteria cukup yang dilakukan pada ibu muda rata-rata yang berusia 20-25 tahun. sehingga dapat memungkinkan untuk melakukan manajemen laktasi secara optimal. dimana pada usia tersebut merupakan masa usia dewasa awal (WHO,2017)

Dari uraian diatas peneliti dapat menyimpulkan terdapat hubungan yang signifikan antara umur dan perilaku ibu primipara dalam manajemen laktasi. Sehubungan dengan hal tersebut keadaan responden yang di atas cenderung mempunyai perilaku yang positif dibandingkan umur yang dibawahnya. Sehingga pada usia tersebut sangat di mungkinkan untuk melakukan proses manajemen laktasi secara baik dan benar.

\section{Karakteristik Responden Berdasarkan Pendidikan}

Pendidikan terbanyak pada kelompok audio visual yaitu tingkat SMA/ MA sebanyak 7 responden (35\%), sampel terendah pada tingkat sarjana sebanyak 1 responden $(5 \%)$. Sampel pendidikan terbanyak pada kelompok. poster yaitu tingkat SMP/Mts sebanyak 8 responden $(40 \%)$, sampel pendidikan terendah yaitu tingkat sarjana sebanyak 2 responden (10\%).

Menurut Kusmiati konsep utama yang mempengaruhi perilaku adalah pendidikan. Pendidikan akan mempengaruhi proses belajar seseorang, makin tinggi pendidikan seseorang makin mudah orang tersebut menerima informasi, seseorang yang berpendidikan tinggi akan berbeda perilakunya dengan orang yang berpendidikan rendah. Tetapi ada faktorfaktor lain yang mungkin akan mempengaruhi pengetahuan yang dimiliki seseorang seperti tingkat kecerdasan, minat dan motivasi seseorang dalam hal tertentu, daya ingat yang dimiliki seseorang yang pasti akan berbeda(Kusmiati, 2007).

Berdasarkan hasil penelitian sebelumnya yang dilakukan oleh satino tentang analisis faktor yang mempengaruhi pemberian ASI eksklusif pada ibu primipara di kota Surakarta $80 \%$ responden mempunyai perilaku yang baik dalam pemberian ASI eksklusif. 60\% (30 responden) dengan perilaku baik dalam pemberian ASI eksklusif yang memiliki pendidikan tinggi (diploma, sarjana, pasca sarjana), $18 \%$ (9 responden) dengan pendidikan sedang (SMP, SMA) dan $2 \%$ (1 responden) dengan pendidikan rendah

http://jurnalilmiah.stikescitradelima.ac.id/index.php/JI Vol.3,No.2, Januari 2020 
(SD) (Satino, 2014). Sriyono (2015) mengatakan bahwa tinggi rendahnya tingkat pendidikan seseorang menentukan pengetahuan, sikap dan perilakunya.

Tingkat pendidikan tidak hanya mempengaruhi tingkat pengetahuan seseorang, namun juga kemampuan penerimaan informasi. Setaranya tingkat pendidikan responden pada penelitian in diharapkan agar kemampuan pemahaman informasi sama antar responden. Hal tersebut dibuktikan dengan hasil posttest responden yang berada pada rentang tingkat pengetahuan yang sama dan dapat menunjukkan bahwa kemampuan pemahaman pendidikan kesehatan yang diberikan sama antar responden sesuai dengan intervensi yang diterimanya (Sriyono, 2015).

Hasil penelitian dilakukan oleh peneliti didapatkan sebagian besar ibu primipara berperilaku kurang sebelum dilakukan pendidikan kesehatan dikarenakan belum pernah mendapatkan informasi yang benar tentang manajemen laktasi yang pada akhirnya akan mempengaruhi perilaku ibu primipara dalam melakukan manajemen laktasi yang baik dan benar. Hal tersebut disebabkan karena mayoritas pendidikan yang tempuh oleh ibu primipara hanya sampi tingkat SMP/Mts dan SMA/MA dimana mereka hanya mendapatkan pendidikan dasar sehingga kurang mendapat pengetahuan kesehatan yang lebih banyak terutama mengenai ASI eksklusif. Selain itu pengetahuan responden juga dipengaruhi oleh pengalaman yang masih sedikit dalam merawat anak karena responden baru memiliki anak pertama.

\section{Hasil Analisis Perilaku Ibu Primipara Sebelum dan Sesudah Pada Kelompok Audio Visual}

Hasil penelitian menunjukkan rata- rata perilaku sebelum dilakukan pendidikan kesehatan menggunakan audio visual adalah 45,65 sedangkan rata-rata sesudah dilakukan pendidikan kesehatan adalah 2,03. Terlihat nilai mean perbedaan antara sebelum dan sesudah adalah 43,62 . Hasil uji statistik didapatkan nilai $\mathrm{p}=0.00$ dan $\alpha=0,05(\mathrm{p}<\alpha)$.

Hasil penelitian ini dikuatkan oleh penelitian sebelumnya yang dilakukan oleh Waldani tentang Pengaruh Penyuluhan Gizi Terhadap Perubahan Perilaku Kebiasaan Sarapan Pagi Murid SD Negeri 05 Solok Selatan menggunakan media film/video mengungkapkan hasil penelitiannya didapat ada perubahan rata-rata nilai pengetahuan, sikap dan tindakan murid tentang sarapan pagi sebelum dan sesudah penyuluhan $(\mathrm{p}<\alpha)$ dan terdapat perbedaan pengetahuan, sikap dan tindakan murid tentang sarapan pagi sebelum dan sesudah penyuluhan $(\mathrm{p}>\alpha)$ (Waldani, Rasyid, \& Agus, 2016).

Penelitian sebelumnya juga dilakukan oleh Harahap pada tahun 2013 tentang Pengaruh Media Visual dan Cetak Pada Pengetahuan Gizi, Sikap, dan Perilaku Ibu Terhadap Sarapan Sehat Anak Sekolah Di SDN Terpilih Kota Depok Tahun 2013, dimana hasil penelitiannya menyimpulkan bahwa media visual dan cetak mampu memengaruhi pengetahuan gizi ibu tentang sarapan sehat $(\mathrm{p}<0,05)$ (Harahap ILW, 2013). Media audio visual merupakan media yang sangat berperan dalam perubahan peilaku responden. Hal ini dikarenakan media audio visual memiliki beberapa kelebihan, yaitu media gambar hidup yang dapat dilihat dan didengar secara bersamaan. Hal ini sesuai dengan pendapat Amri Jahi (2006) bahwa Media audio visual adalah media instruksional modern yang sesuai dengan perkembangan jaman (kemajuan ilmu pengetahuan dan teknologi), meliputi media yang dapat dilihat, didengar, dan dapat dilihat dan didengar.

Hasil penelitian yang sudah dilakukan di Puskesmas Taman Krocok didapatkan perubahan perilaku pada ibu primipara sesudah dilakukan pendidikan kesehatan menggunakan media audio visual, hal ini dikarenakan menggunakan media audio visual tergolong media yang efektif. Hal ini disebabkan karena media audio visual lebih menarik, tidak membosankan karena bergambar hidup dan mudah dipahami. Responden lebih tertarik untuk menonton (melihat) dan mendengarkan, sehingga peningkatan perilaku responden menjadi lebih baik. Dari uraian diatas peneliti dapat menyimpulkan ada pengaruh yang signifikan pada perilaku ibu primipara sesudah dilakukan pendidikan kesehatan menggunakan media audio visual dalam manajemen laktasi.

\section{Hasil Analisis Perilaku Ibu Primipara Sebelum dan Sesudah Pada Kelompok Poster}

Hasil penelitian didapatkan nilai rata-rata perilaku sebelum dilakukan pendidikan kesehatan menggunakan poster adalah 47,55 sedangkan rata-rata sesudah dilakukan pendidikan kesehatan adalah 2,04. Terlihat nilai mean perbedaan antara sebelum dan sesudah adalah 45,51 . Hasil uji statistik didapatkan nilai $\mathrm{p}=0.00$ dan $\alpha=0,05(\mathrm{p}<\alpha)$.

http://jurnalilmiah.stikescitradelima.ac.id/index.php/JI Vol.3,No.2, Januari 2020 
Penelitian ini dikuatkan oleh penelitian sebelumnya yang dilakukan oleh Zakiyatul Ulya tentang Pengaruh Pendidikan Kesehatan Menggunakan Media Poster Terhadap Pengetahuan Manajemen Hipertensi Pada Penderita Hipertensi mengemukakan Hasil uji Paired t-test terdapat perbedaan peningkatan pengetahuan yang signifikan pada kelompok intervensi $(\mathrm{p}=0,000)$ dibandingkan kelompok kontrol $(\mathrm{p}=0,194)$ sesudah dilakukan pendidikan kesehatan (Zakiyatul Ulya, Asep Iskandar, 2017).

Penelitian sebelumnya juga dilakukan oleh Roihatul tentang Pendidikan Kesehatan Meningkatkan Motivasi Ibu Primipara dalam Memberikan Asi, hasil yang diperoleh terdapat perubahan dalam pemberian Asi sesudah dilakukan pendidikan kesehatan dengan nilai $\mathrm{p}=0,000$ mana $\mathrm{p}<0,05$ maka $\mathrm{H0}$ ditolak (Roihatul Zahroh, 2014). Menurut Suliha (2002), pendidikan kesehatan yang sudah menjadi bentuk tindakan mandiri keperawatan diharapkan mampu mengubah perilaku individu, kelompok maupun masyarakat yang merupakan cara Berpikir, Bersikap Dengan Tujuan Membantu pengobatan, rehabilitasi, pencegahan penyakit dan promosi hidup sehat. Teori tersebut sejalan dengan Teori tersebut sesuai dengan adanya perubahan perilaku ibu primipara dalam manajemen laktasi dikarenakan setelah diberikan pendidikan kesehatan tentang manfaat ASI, motivasi yang semula sedang bertambah menjadi motivasi tinggi untuk melakukan manajemen laktasi dengan baik (Suliha, 2002).

Pada penelitian yang dilakukan di Puskesmas Taman Krocok peneliti dapat menyimpulkan bahwa ada pengaruh yang signifikan terhadap peningkatan perilaku ibu primipara setelah dilakukan pendidikan kesehatan tentangmanajemen laktasi menggunakan media cetak yang berbentuk poster. Hal ini disebabkan ibu primipara mendapatkan informasi tentang pentingnya pemberian ASI pada bayi dan ketertarikan ibu primipara pada media poster tersebut, karena menurut responden poster hanyalah sebatas kertas yang ditempel, sehingga setelah diberikan pendidikan kesehatan motivasi ibu makin bertambah. Pendidikan kesehatan menyebabkan ibu berperilaku baik dalam melakukan manajemen laktasi untuk meningkatkan pemberian ASI eksklusif dan menyambut positif dengan program pemberian ASI eksklusif selama 6 bulan.

\section{Hasil analisis Perbandingan Perilaku Pada Kelompok Audio Visual dan Poster}

Hasil penelitian yang dilakukan di Puskesmas Taman Krocok diketahui bahwa kelompok audio visual memiliki nilai rata-rata lebih tinggi dari pada kelompok poster. Sehingga, dapat diartikan bahwa metode pendidikan kesehatan menggunakan media audio visual lebih efektif untuk meningkatkan perilaku ibu primipara dalam manajemen laktasi.

Penelitian ini sejalan dengan penelitian sebelumnya yang dilakukan oleh Dian Rahmawati tentang Efektifitas Modul Untuk Manajaman Laktasi Pasca Melahirkan, didapatkan hubungan yang sangat bermakna antara penggunaan modul dengan pengetahuan ibu tentang manajemen laktasi pasca melahirkan ( $\mathrm{p}=0,000)$ (Dian Ramawati, Lutfatul Latifah, 2013).

Penelitian ini sejalan dengan penelitian sebelumnya yang dilakukan oleh Kholisotin tentang efektifitas paket pendidikan preklamsia terhadap pengetahuan, sikap, dan keterampilan perempuan hamil terhadap resiko preeklamsia di situbondo terdapat pengaruh yang signifikan tentang pemberian paket edukasi terhadap perempuan hamil yang beresiko preeklamsia (Kholisotin, , 2017)

Penelitian sebelumnya juga dilakukan oleh Andriany pada anak SDN 24 Banda Aceh mengenai perbandingan efektifitas media penyuluhan poster dan kartun animasi terhadap pengetahuan kesehatan gigi dan mulut. Hasil penelitian menunjukkan animasi yang merupakan media audio visual lebih efektif dalam meningkatkan pengetahuan kesehatan gigi siswa (Andriany, 2016).

Penelitian sebelumnya juga dilakukan oleh Zakarias (2016) mengemukakan Pemberian pendidikan kesehatan gigi dan mulut menggunakan media video dan flip chart efektif terhadap peningkatan pengetahuan kesehatan gigi dan mulut anak. PKG menggunakan media video lebih efektif dalam meningkatkan pengetahuan kesehatan gigi dan mulut anak dibandingkan menggunakan media flip chart (Kantohe, Vonny N. S. Wowor, \& Gunawan, 2016). Hal ini juga diperjelas oleh pendapat Rahmawati (2007) bahwa audio visual merupakan alat bantu yang paling tepat saat ini sebab pengetahuan yang ada pada seseorang diterima melalui indera mencapai $75 \%$ sampai $87 \%$ dari pengetahuan manusia diperoleh atau disalurkan melalui indera pandang dan $13 \%$ melalui indera dengar (Rahmawati, I., T. Sudargo, 2007).

http://jurnalilmiah.stikescitradelima.ac.id/index.php/JI Vol.3,No.2, Januari 2020 
Hal ini sesuai dengan fase-fase yang terjadi setelah mendapat pendidikan kesehatan dimana tujuan dan hasil yang diharapkan dari pendidikan kesehatan berupa penambahan pengetahuan, perubahan kebiasaan dan proses menyadarkan orang lain dalam berperilaku. Dalam teori Benyamin Blum menyatakan bahwa pengetahuan atau kognitif merupakan domain yang sangat penting untuk terbentuknya tindakan seseorang. Dalam teori tersebut dijelaskan pula bahwa perilaku merupakan faktor terbesar kedua setelah faktor lingkungan yang mempengaruhi kesehatan individu atau masyarakat. Oleh sebab itu, dalam rangka membina kesehatan masyarakat, intervensi terhadap faktor perilaku sangat strategis. Selain itu, pengetahuan tentang suatu objek tertentu sangat penting bagi terjadinya perubahan perilaku yang merupakan proses yang sangat kompleks. Perilaku yang didasari oleh pengetahuan akan lebih baik daripada perilaku yang tidak didasari oleh pengetahuan. WHO juga mengungkapkan bahwa seseorang berperilaku tertentu disebabkan oleh pemikiran dan perasaan dalam bentuk pengetahuan, persepsi, sikap, kepercayaan, dan penilaian-penilaian seseorang terhadap objek. Dalam hal ini, dengan pemberian penyuluhan kesehatan maka pengetahuan akan bertambah sehingga praktik juga akan lebih baik.

\section{SIMPULAN}

Berdasarkan hasil penelitian yang dilakukan di Puskesmas Taman Krocok dapat disimpulkan bahwa ada perbedaan tingkat keefektifan pendidikan kesehatan menggunakan audio visual dan Poster terhadap perilaku ibu primipara dalam manajemen laktasi.

\section{DAFTAR PUSTAKA}

Andriany. (2016). Perbandingan efektifitas media penyuluhan poster dan kartun animasi terhadap pengetahuan kesehatan gigi dan mulut, 1(1), 6572.

Dian Ramawati, Lutfatul Latifah, E. R. (2013). EFEKTIVITAS MODUL UNTUK MANAJEMEN LAKTASI PASCA MELAHIRKAN, 8(1), 49-55.

Harahap ILW . (2013). Pengaruh media visual dan cetak pada pengetahuan gizi, sikap, dan perilaku ibu terhadap sarapan sehat anak sekolah di SDN terpilih Kota Depok tahun 2013.
Kantohe, Z. R., Vonny N. S. Wowor, \& Gunawan, 2Paulina N. (2016). Perbandingan efektivitas pendidikan kesehatan gigi menggunakan media video dan flip chart terhadap peningkatan pengetahuan kesehatan gigi dan mulut anak, 4, 7-12.

Kholisotin, (2017). The Effectiveness Of Preclampsia Educational Package To The Knowledge, Attitude, And Skill Of Pregnant Women At Risk Of Preeclampsia In Situbondo, Universitas Muhammadiyah Jakarta.

Kusmiati, S. (2007). Dasar-dasar Perilaku. Jakarta: Depkes RI

.Maritalia, D. (2017). Asuhan Kebidanan Pada Ibu Nifas. Yogyakarta: Gosyen.

Notoatmodjo, S. (2010). Ilmu Perilaku Kesehatan. ( soekidjo Notoatmojo, Ed.) (2010th ed.). Jakarta: Rineka Cipta.

Prasetyono, dwi sunar. (2009). Asi Ekslusif, pengenalan, praktik, dan kemanfaatankemanfaatannya. Yogyakarta: diva press.

Rahmawati, I., T. Sudargo, dan I. P. (2007). Pengaruh Penyuluhan dengan Media Audio Visual Terhadap Peningkatan pengetahuan, Sikap Balita Gizi Kurang dan Buruk Dikabupaten kota Waringin Barat Propinsi Kalimantan Tengah, 4, 69-77.

Roesli. (2008). Manajemen Laktasi. jakarta: ikatan dokter indonesi.

Roihatul Zahroh, M. I. L. (2014). Pendidikan Kesehatan Meningkatkan Motivasi Ibu Primipara Dalam Memberikan Asi, 5(1), 56-62.

Sartono, A. (2012). Hubungan Pengetahuan Ibu , Pendidikan Ibu dan Dukungan Suami dengan Praktek Pemberian Asi Eksklusif di Kelurahan Muktiharjo Kidul Kecamatan Telogosari Kota Semarang, 1(November), 1-9.

Sarwono. (2000). Teori- teori psikologi sosial. Jakarta: Raja Gravindo Persada.

Satino, yuun setiyorini. (2014). Analisis Faktor Yang Mempengaruhi Pemberian Asi Eksklusif Pada http://jurnalilmiah.stikescitradelima.ac.id/index.php/JI Vol.3,No.2, Januari 2020 
Ibu Primipara Di Kota Surakarta Satino, Yuyun Setyorini.

Sriyono. (2015). Pengaruh Tingkat Pendidikan dan

Pemahaman Masyarakat tentang Ikan

Berformalin Terhadap Kesehatan Masyarakat,

Faktor Exacta, 8(1), 79-91.

Suliha. (2002). Pendidikan Kesehatan dalam Keperawatan. Jakarta: EGC.

Timur, P. J. (2017). PROVINSI JAWA TIMUR.

Waldani, D., Rasyid, R., \& Agus, Z. (2016). Pengaruh Penyuluhan Gizi Terhadap Perubahan Perilaku Kebiasaan Sarapan Pagi Murid SD Negeri 05 Solok Selatan Tahun 2016, 7(2), 176-181.

Zakiyatul Ulya, Asep Iskandar, F. T. A. (2017). Pengaruh Pendidikan Kesehatan Dengan Media Poster

Terhadap Pengetahuan Manajemen Hipertensi Pada Penderita Hipertensi, 12(1), 38-46.

Zuhrotul Eka Yulis Anggraeni (2016). Evaluasi Managemen Laktasi Ibu Muda Di Posyandu Rambutan 5*, 6(2), 187-191 